\title{
Comparison between computed and measured fibre orientation in injection moulded parts
}

\author{
A. Kech ${ }^{1}$, M. Vincent ${ }^{2}$, V. Hosdez ${ }^{1}$ \\ ${ }^{1}$ Robert Bosch GmbH, Corporate Sector Research and Advance Engineering Advance Production Technology \\ 1 Plastics Engineering- P. O. Box 11 31, D - 71301 Waiblingen, Germany \\ URL: $\underline{\text { www.bosch.com }}$ \\ e-mail:Armin.Kech@de.bosch.com \\ ${ }^{2}$ Ecole Nationale Supérieure des Mines de Paris, Centre de Mise en Forme des Matériaux- 1, rue Claude \\ Daunesse, F-06904 SOPHIA ANTIPOLIS Cedex, France \\ URL: $\underline{w w w-c e m e f . c m a . f r}$ \\ e-mail: michel.vincent@ensmp.fr
}

\begin{abstract}
Short fibre reinforced thermoplastic materials play an important role in automotive industries due to their excellent processing behaviour, reasonable good mechanical performance, high design freedom and low prices. Although the thermo-mechanical requirements for the used materials increase, the development cycles decrease. Numerical methods based on the finite element analysis (FEA) can be a strong assistant when judging designs and reducing cost and time consuming experimental tests. The mechanical properties for short fibre reinforced thermoplastics are mainly dominated by the fibre orientation resulting from the injection moulding process. Several commercial tools offering 3D flow simulation are on the market, each of them with strengths and weaknesses and many opportunities for future application in part design. In cooperation with Ecole Nationale Supérieure des Mines de Paris a study was carried out in order to compare two different injection moulding simulation tools (MOLDFLOW MPI ${ }^{\circledR}$ and REM-3D®) with experimental data concerning the prediction of fibre orientation distribution. The study includes investigations on the accuracy and sources of measurement errors on the well-established surface ellipse method on polished surfaces. It gives an overview on the state-of-the art in this field. On the other hand simulation results compared with measurements on a sample geometry taken at different locations indicate that the accuracy of the simulation also needs some improvement. Areas of fairly good agreement and others with significant differences are discussed. The importance of accurate fibre orientation on subsequent thermo-mechanical analysis is stressed by comparing experimental data with simulated deformation behaviour. As a conclusion, alternatives both for experimental setup and algorithms used for the numerical prediction of fibre orientation, so far based on the well-known Folgar-Tucker model are proposed. The limitations of this model for real parts are also discussed.
\end{abstract}

Key words: Short fibre reinforced thermoplastics, simulation

\section{INTRODUCTION}

For the product development of plastic components of short fibre reinforced thermoplastics the time-tomarket and quality assurance are increasing demands.

Advanced numerical simulation methods based on FEA can contribute to safe time and money by avoiding ineffective testing and improper designs. This study was started in order to investigate the current state of the art for automotive applications. The challenge nowadays is the combination of process simulation to improve part design and injection moulding process and structural mechanical tools taking into account the calculated fibre orientation from process simulations. The workflow is shown in figure 1 . The simulation tools used were MOLDFLOW MPI ${ }^{\circledR}$ (3D module) and REM $3 D \AA$ for injection moulding simulations and ABAQUS ${ }^{\circledR}$ for structural mechanics calculation. The demands for meshes in flow dynamics for fibre reinforced materials differ significantly from those in structural mechanics. Therefore, an interface is required to map calculated fibre orientation results from a fine $3 \mathrm{D}$ mesh in process simulation to a 
coarse mesh in FEA codes.

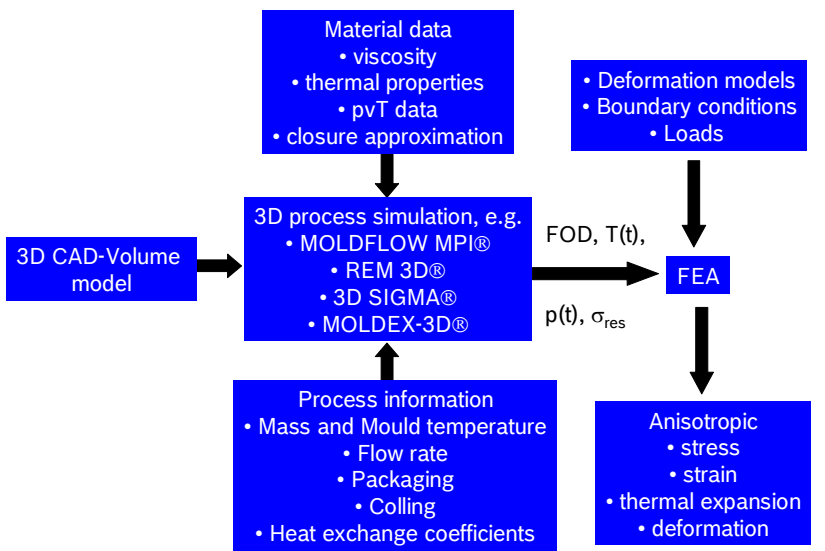

Fig. 1: The workflow for process simulation in the part design of short fibre reinforced thermoplastic components

\section{EXPERIMENTAL AND NUMERICAL RESULTS}

\subsection{Experimental setup}

In order to test the accuracy of the calculated fibre orientation a simple geometry was used. A plate with a diverging entrance, $2 \mathrm{~mm}$ thickness and area of $80 \times 80 \mathrm{~mm}^{2}$ was injection moulded with different moulding parameters.

The material used is one of the common used materials in automotive industries for housing of electrical components, PBT with a short glass fibre content of 30 wt. $\%$.

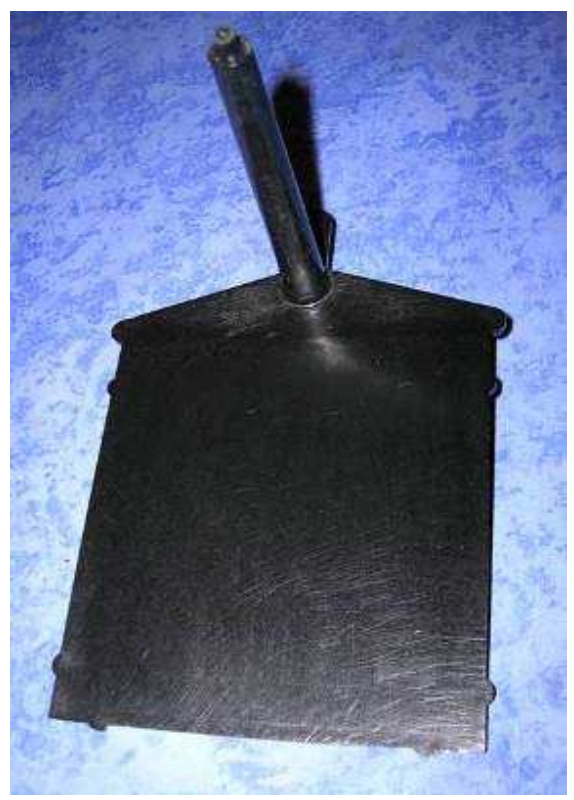

Fig. 2: The investigated plate geometry

For the sake of comparison, the flow pattern as well as the fibre orientation distributions was evaluated.

\subsection{MOLDFLOW MPI®}

The plate was meshed with linear tetrahedral elements for use in MOLDFLOW MPI ${ }^{\circledR}$ Version 5.1, Rev. 3. The 3D module was used, taking into account inertia and neglecting gravity effects.

Cooling channels and mould dimensions were not modelled, i.e. a constant mould temperature was assumed. The heat exchange coefficient was set to $2500 \mathrm{~W} / \mathrm{m}^{2} \mathrm{~K}$. Fibre orientation distribution was calculated based on the Folgar-Tucker equations [1]. To increase the accuracy of the fibre orientation calculation 8 elements over thickness were used.

\section{$2.3 R E M-3 D \circledR$}

Version 3.1 of REM-3D® was used and had, for the first time, an implemented fibre orientation calculation based on the same model as that of MOLDFLOW MPI ${ }^{\circledR}$. The required mesh quality in REM-3D ${ }^{\circledR}$ is higher than in MOLDFLOW MPI ${ }^{\circledR}$ which affects the calculation time and results in a slightly better agreement concerning flow pattern prediction, see figure 3 and table 1 .

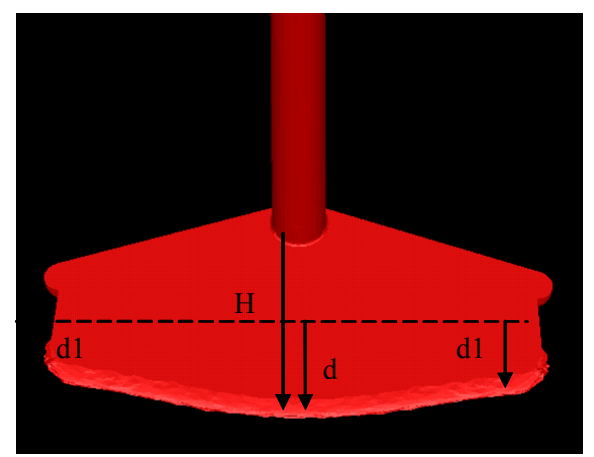

Fig. 3: A flow pattern; definition of characteristic measures

Table 1: Short shot studies compared with simulated results

\begin{tabular}{|l|l|l|l|}
\hline \% of filling & Real injection & $\begin{array}{l}\text { MOLDFLOW } \\
\text { MPI® }\end{array}$ & REM-3D® \\
\hline 17 & $\mathrm{H}=10$ & $\mathrm{H}=9$ & $\mathrm{H}=10$ \\
\hline 34 & $\mathrm{~d}=6$ & $\mathrm{~d}=5$ & $\mathrm{~d}=5.6$ \\
& $\mathrm{~L}=73$ & $\mathrm{~L}=55$ & $\mathrm{~L}=63$ \\
\hline 51 & $\mathrm{~d}=24$ & $\mathrm{~d}=20$ & $\mathrm{~d}=21$ \\
& $\mathrm{~d}_{1}=17$ & $\mathrm{~d}_{1}=9.5$ & $\mathrm{~d}_{1}=13$ \\
\hline 68 & $\mathrm{~d}=46$ & $\mathrm{~d}=40.4$ & $\mathrm{~d}=39$ \\
& $\mathrm{~d}_{1}=42$ & $\mathrm{~d}_{1}=34$ & $\mathrm{~d}_{1}=34.5$ \\
\hline 85 & $\mathrm{~d}=65$ & $\mathrm{~d}=62$ & $\mathrm{~d}=63.5$ \\
& $\mathrm{~d}_{1}=62$ & $\mathrm{~d}_{1}=55.5$ & $\mathrm{~d}_{1}=50.5$ \\
\hline
\end{tabular}

In order to spare calculation time and storage, only half of the plate was modelled in REM-3D®. 


\subsection{Fibre orientation distribution}

The fibre orientation distribution was measured using a surface ellipse method on polished surfaces [2]. Samples were taken parallel and perpendicular to the flow direction on various positions of the plate, see figure 4 . The polished surfaced were investigated with SEM at 500x and $1000 \mathrm{x}$ magnification at CEMEF. For image analysis, the software VISILOG® was used.

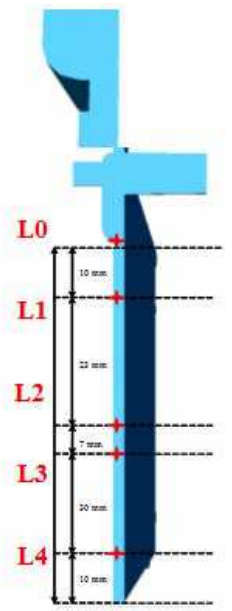

Fig. 4: Positions of samples taken for fibre orientation distribution

The method implies several sources of error which are listed in table 2.

Table 2: Sources of error for fibre orientation distributions

\begin{tabular}{|c|c|c|c|}
\hline Error name & Cause & Induced error & $\begin{array}{l}\text { Source of } \\
\text { evaluation }\end{array}$ \\
\hline $\begin{array}{l}\text { Experimental } \\
\text { disturbances }\end{array}$ & Polishing & Unknown & None \\
\hline $\begin{array}{l}\text { Reproducibility } \\
\text { uncertain }\end{array}$ & $\begin{array}{l}\text { Injection } \\
\text { moulding } \\
\text { process } \\
\end{array}$ & $\begin{array}{l}\text { From } 0.01 \text { to } \\
0.07\end{array}$ & $\begin{array}{l}\text { Present } \\
\text { study }\end{array}$ \\
\hline $\begin{array}{l}\text { Sampling } \\
\text { errors }\end{array}$ & $\begin{array}{l}\text { SEM, } \\
\text { VISILOG }\end{array}$ & 0.05 & $\begin{array}{l}\text { Eberhardt et } \\
\text { al [3] }\end{array}$ \\
\hline $\begin{array}{l}\text { Number of } \\
\text { fibres }\end{array}$ & $\begin{array}{l}\text { Number of } \\
\text { fibres in the } \\
\text { scanned area }\end{array}$ & $\begin{array}{l}0.01 \text { to } 0.015 \\
\text { for } 500 \text { and } \\
1000 \\
\text { magnification }\end{array}$ & $\begin{array}{l}\text { Eberhardt et } \\
\text { al [3] }\end{array}$ \\
\hline $\begin{array}{l}\text { Systematic } \\
\text { error }\end{array}$ & $\begin{array}{l}\text { SEM, } \\
\text { VISILOG® }\end{array}$ & $\begin{array}{l}\text { Dependent } \\
\text { on the tensor } \\
\text { coefficient } \\
\text { value }\end{array}$ & $\begin{array}{l}\text { Present } \\
\text { study }\end{array}$ \\
\hline $\begin{array}{l}\text { Borderkill } \\
\text { error }\end{array}$ & VISILOG® & $\begin{array}{l}\text { Highly } \\
\text { dependent on } \\
\text { the tensor } \\
\text { coefficient } \\
\text { value }\end{array}$ & $\begin{array}{l}\text { Present } \\
\text { study }\end{array}$ \\
\hline Angular error & Probe cut & $\begin{array}{l}0.001 \\
\text { dependent on } \\
\text { the tensor } \\
\text { coefficient } \\
\text { value }\end{array}$ & None \\
\hline
\end{tabular}

\begin{tabular}{|l|l|l|l|}
\hline $\begin{array}{l}\text { Intersection } \\
\text { probability }\end{array}$ & $\begin{array}{l}\text { Distribution } \\
\text { of fibre } \\
\text { lengths }\end{array}$ & $<0.01$ & $\begin{array}{l}\text { Present } \\
\text { study }\end{array}$ \\
\hline
\end{tabular}

The comparison of the simulated and measured data shows differences dependent on the position where the samples were taken, see figure 5 and 6 .
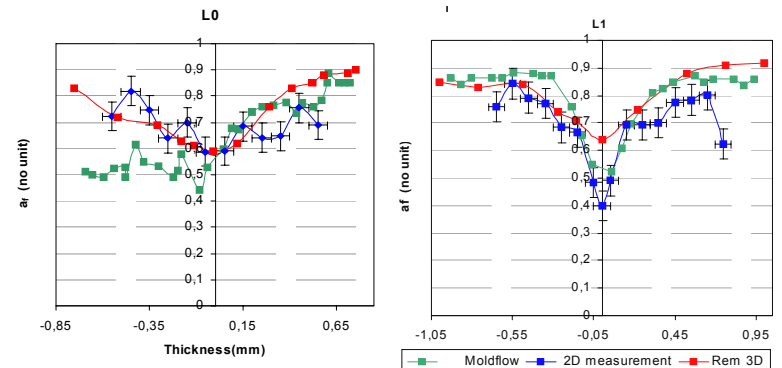

Fig. 5: Comparison of fibre orientation distribution
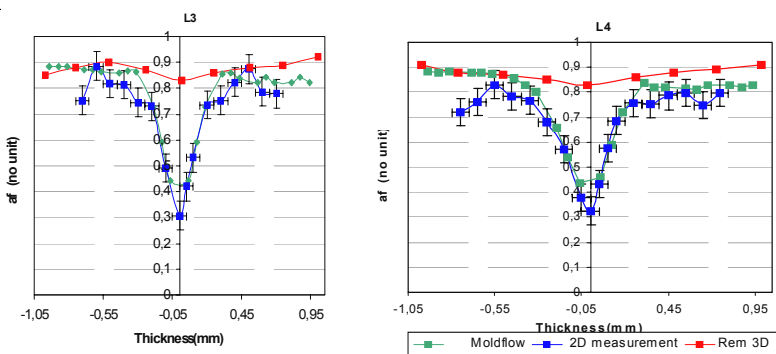

Fig. 5: Comparison of fibre orientation distribution

Especially the area with a high alignment of fibres near the surface was overestimated by the simulation. The REM-3D ${ }^{\circledR}$ results are only preliminary since the module was still under development when the present study was carried out. The influence of errors in the fibre orientation prediction on mechanical properties was investigated by Caton-Rose et al [4]. The cited study demonstrated that the predictions of fibre orientation based on the Folgar-Tucker model are highly affected by an empirical value called the interaction coefficient. Although defined as a material property it shows dependencies also on geometrical characteristics.

\section{CONCLUSIONS}

The present study showed that fibre orientation prediction bases on the well-known Folgar-Tucker equations show qualitatively good agreement with experimental data. There is a tendency of overestimations of aligned areas and there is a strong dependency on the mesh size. However comparison with experimental data is rather difficult. Efforts regarding the use of new approaches based on real 
3D non-destructive methods have just recently been published or are based on systems with low fibre contents. Future development in this area is required.

\section{ACKNOWLEDGEMENTS}

The presented study was partially funded by the European Community (PIAM, project number: NMP2-CT-2003-505878). The REM-3D ${ }^{R}$ simulations were kindly supported by Transvalor S.A.

\section{REFERENCES}

1. Folgar, F., Tucker, Ch. L., 'Orientation Behaviour of Fibers in Concentrated Suspensions', J. Reinforced Plastics and Composites, Vol. 3, 1984
2. Clarke, A., Eberhardt, C., 'Fibre-orientation measurements in short-glass-fibre composites. Part I: automated, high-angular-resolution measurements by confocal microscopy', Composites Science and Technology 61 (2001), 1389 - 1400

3. Eberhardt, C., Clarke, A., Vincent, M., Giroud, T., Flouret, S. 'Fibre-orientation measurements in short-glassfibre composites - II a quantitative error estimate of the 2D image analysis technique', Composites Science and Technology 61 (2001), 1961-1974

4. Caton-Rose, P., Hine, P. J., 'Mechanical Property Predictions in Fibre Reinforced Polyamide Injection Moulded Parts, Using Measured and predicted Fibre Orientation within ABAQUS', $21^{\text {st }}$ Annual Meeting of the PPS, 2005, Leipzig 